\title{
Freedom as ethical practices: on the possibility of freedom through freeganism and freecycling in Hong Kong
}

\section{Loretta leng Tak Lou}

To cite this article: Loretta leng Tak Lou (2019): Freedom as ethical practices: on the possibility of freedom through freeganism and freecycling in Hong Kong, Asian Anthropology, DOI: 10.1080/1683478X.2019.1633728

To link to this article: https://doi.org/10.1080/1683478X.2019.1633728

曲 Published online: 05 Jul 2019.

Submit your article to this journal $\pi$

View Crossmark data $₫$ 


\title{
Freedom as ethical practices: on the possibility of freedom through freeganism and freecycling in Hong Kong
}

\author{
Loretta leng Tak Lou (DD \\ Department of Sociology, University of Macau, Taipa, Macau SAR
}

\begin{abstract}
Although the idea of freedom has been well studied as an ideal in political philosophy, relatively little scholarship has focused on the human experience of freedom. Drawing on ethnographic research between 2012 and 2013, I examine how freedom was achieved by people who practice freeganism and freecycling in Hong Kong. I show that the freedom that these people pursue, either individually or collectively, is not a freedom without constraints but a freedom that must be attained through the exercise of deliberation, restraint, and self-discipline. While freegans seek liberation by withdrawing from the world and practicing self-cultivation (chushi asceticism), freecyclers do so by engaging with worldly affairs in order to create social changes (rushi asceticism). In both cases, by reimagining freedom as ethical practices rather than a right that comes naturally with birth, freegans and freecyclers in Hong Kong are able to experience moments of freedom despite inevitable structural constraints.
\end{abstract}

\section{KEYWORDS}

Hong Kong; freedom;

freeganism; freecycle; anti-

consumption

In Hong Kong, freedom (自由 ziyou) ${ }^{1}$ is widely considered a core value that defines many of its political and cultural identities, ${ }^{2}$ especially in relation to the "nonfreedom" in mainland China. When the people of Hong Kong talk about freedom, what they are usually referring to is economic freedom and freedom of speech-the two kinds of freedom that are thought to differentiate Hong Kong from the rest of China. The city is especially proud of the fact that Hong Kong is continuously rated as the world's "freest" economy for the last two decades. And although there are clear signs of gradual erosion of free speech, ${ }^{3}$ Hong Kong people still have relatively more freedom than their counterparts in China in this regard. Ironically, as Pang rightly points out, the freedom that Hong Kong people take pride in is also inhibiting and alienating because such freedom is deeply embedded in capitalism and in the neoliberalist values that shape Hong Kong on all fronts (Pang 2018, 2).

As such, in recent years scholars and public intellectuals in Hong Kong have called for further discussions on how freedom may be reimagined and re-conceptualized in the local context. ${ }^{4}$ However, such attempts have remained largely at a theoretical 
level. ${ }^{5}$ Indeed, even though freedom has been well studied as an ideal in political philosophy, relatively little research has focused on the human experience of freedom. As anthropologists Schut and Grassiani $(2017,8)$ observe, "studies of freedom, or of what it means to be free, are often characterized by a focus on its relative absence". Since freedom tends to be examined within the purview of people's struggle against oppression or as a dream held by the imprisoned, we know very little about freedom as an "experience" or a "subjective state" of those who claim to be free $(2017,8)$.

In my own research on people who strived to live a green and ethical life in Hong Kong (Lou 2016), the notion of freedom came up frequently among those who tried to practice freeganism and freecycling in their everyday life. Freeganism is a way of living "based on limited participation in the conventional economy and minimal consumption of resources" (Freegan.info 2018). Derived from the words "free" and "vegan", freeganism in the West includes anticonsumerist practices like dumpster diving, squatting in abandoned buildings, "guerrilla gardening" in vacant city lots, and foraging wild food (Barnard 2011, 420). Freecycling, on the other hand, is the act of giving and getting items for free, usually from people who live in the same town. It is a global grassroots movement that aims to keep reusable items out of landfills by "changing the world one gift at a time" (Freecycle.org 2019). While neither the freegans nor the freecyclers in Hong Kong claimed that their movements have succeeded in destabilizing the orders that make the "skeleton of this capitalist city" (Pang 2018), like practitioners in other parts of the world, they expressed a sense of liberation from the circuit of capitalism (Barnard 2011; Ernst 2010; Krøijer 2015) even though the entrenchment of certain neoliberal values was evident in their thoughts and practices. But despite this clear link to the practice of freeganism and freecycling (and the fact that both freeganism and freecycle begin with the prefix "free"), it is intriguing that the concept of freedom is absent in current analyses, which tend to contrast both practices with traditional modes of consumption, to discuss them with respect to sustainability, waste, and emerging citizenships (Ankeny 2012; Aptekar 2016; Eden 2017; Nelson, Rademacher, and Hye-Jin 2007; Sari 2010; Moré 2011; Edwards and Mercer 2012), or to place them within the context of new social movements against globalization and neoliberal capitalism (Barnard 2011; Ernst 2010; Krøijer 2015).

Apart from this conceptual blindspot, both freecycling and freeganism require more empirical investigations in non-Western societies. Although anthropologists and other social scientists have demonstrated considerable interest in social movements propelled by certain ethical commitments, namely the alternative food movement (Goodman, DuPuis, and Goodman 2013), the fair-trade movement (De Neve et al. 2012; Nicholls and Opal 2005; Lyon and Moberg 2010), and ethical consumption (Carrier and Luetchford 2012; Connolly and Prothero 2008; Lewis and Potter 2011), research on freeganism and freecycling - let alone their variants in Asia-is surprisingly limited. No anthropological research to date has focused on freeganism in a nonWestern context, nor has there been any study of freecycling beyond Freecycle.org, an online network originated in the United States through which people give and receive second-hand goods from neighbors to prevent items from going into landfills (Eden 2017). 
In this paper, I navigate these terrains by revisiting the concept of freedom through an ethnographic study of freecycling and freeganism. In illustrating how freegans and freecyclers in Hong Kong make an effort to reduce waste and combat overconsumption by pursuing a simpler and less materialistic way of life, I argue that their actions are motivated by a sense of environmental responsibility as much as the desire to attain more personal and political freedom in Hong Kong. This research is based on 14 months of fieldwork in Hong Kong between 2012 and 2013, during which I conducted an ethnographic study of the "green living movement" and its implications for people's self-understanding, social relations, ethics, and social movements (Lou 2016). Freeganism and freecycling are two of the green living practices, among many others, that my informants made an effort to adhere to. I came to know the freegans and freecyclers through referral and by attending a variety of public talks, events, and activities about ethical and green living. Participant observation and interviews (primarily unstructured and semi-structured and completely open-ended) were my main data collection methods, supplemented by critical discourse analysis of news articles and books on this topic.

\section{Freedom and ethical practices}

Before I explore ethnographic details, let me delineate the kind of freedom that the freegans and the freecyclers pursue, and explicate the relationship between freedom and ethical practices. One of the most well-known discussions about freedom in the contemporary history of ideas is Isaiah Berlin's "Two Concepts of Liberty" (1969). ${ }^{6}$ Although my interlocutors in Hong Kong did not explicitly refer to Berlin's "positive" and "negative" freedom, ${ }^{7}$ their conceptions of freedom invariably coincided with the distinction that Berlin made. On the one hand, Berlin argued that in the negative sense of freedom, people are not prevented by others from doing what they would otherwise do (Berlin 1969, 122). In other words, negative freedom is an absence of obstacles, barriers, and interference from others (Carter 2016). On the other hand, positive freedom requires the "presence of something", whether it be self-mastery, self-abnegation, or self-realization (Berlin 1969, 134; Carter 2016). Ultimately, positive freedom derives from "the wish on the part of the individual to be his own master" (Berlin 1969, 131). ${ }^{8}$

As my ethnography will show, the freedom that my interlocutors pursue is not freedom that allows them to do whatever they want without constraints ("negative freedom"), but freedom that must be achieved by transforming oneself or one's society into a better and more ethical state ("positive freedom"). While freegans seek positive freedom through individual self-cultivation, freecyclers aspire to what philosopher Honneth (2017) terms "social freedom". Honneth argues that there should be three rather than two concepts of liberty, because neither positive nor negative freedom is adequate to address the social and cooperative aspect of people's collective aspiration for freedom $(2017,177)$. As such, Honneth puts forth the idea of "social freedom", which "unlike the concept of negative freedom, but like the positive concept", addresses a "form of cooperative freedom that is evidently performed in the social practices of democratic participation" (2017, 190, 184). Most importantly, social 
freedom does not assume a subject of unrestrained capacity to do whatever he or she wishes (i.e. negative freedom), "but rather one that is bound to the existence of certain social conditions, namely, belonging to a community of ethically concordant members" $(2017,190)$, such as the freecycle communities in Hong Kong.

The individual characteristic of freeganism and the collective characteristic of freecycling result in two contrasting approaches to the attainment of freedom in Hong Kong. Inspired by Weber's ([1922] 1978) distinction between "inner-worldly asceticism" (characterizing ascetics who seek merit through changing the everyday world) and "other-worldly asceticism" (practiced by ascetics who seek merit beyond the everyday world), but drawing more directly from vernacular expressions, I describe the freegans' approach to freedom as a kind of "chushi asceticism" and the freecyclers' more collective pursuit of freedom as "rushi asceticism". Having roots in traditional Chinese philosophical and religious thinking, the idea of rushi (入世), literally "entering the world", is to foster social change, whereas chushi (出世), "withdrawing from the world", implies a retreat from worldly affairs and a focus on self-cultivation (Brook 1994, 70).

Regardless of their difference in approaches, both freegans and freecyclers in Hong Kong acknowledge the significance of ethical practices in their pursuit of individual and social freedom. In anthropology, however, interest in ethics, especially the relationship between ethics and freedom, have been rarely explored until James Laidlaw published a landmark paper entitled "For an anthropology of ethics and freedom" (Laidlaw 2002). With the recent "ethical turn", anthropologists no longer saw morality and ethics as just "a set of norms and values for a given group or society" (Fassin 2014), but also as "an anthropological problem for investigation" (Kelty 2011a,b). They began to see that their knowledge about the diversity of moral life could contribute to "debates among philosophers and others about how to understand ethics" (Laidlaw 2017). Among the burgeoning work and debates in this field (Robbins 2007; Keane 2014; Heywood 2015; Dyring 2018), Laidlaw's writing is the most relevant to the Hong Kong case (Laidlaw 2002, 2014). Building on Foucault's later ideas on ethical self-cultivation as an exercise of freedom (Foucault 1997), ${ }^{9}$ Laidlaw argues that it is possible to experience freedom by actively reflecting on the question of "how one ought to live", by which he means not only living according to "socially sanctioned moral rules" (Foucault 1988; Laidlaw 2002, 321) but also in accord with the process of ethical selffashioning (Foucault 1997, 284; Laidlaw 2002, 322-324). In this article, I draw on Laidlaw's notion of "ethical freedom" (or "reflective freedom" as he sometimes calls it) (Laidlaw 2002, 2017) to make the case that if we imagine freedom as ethical practices rather than as a right that comes naturally with birth, as the freegans and the freecyclers in Hong Kong do, we may be able to experience moments of freedom despite inevitable structural constraints.

\section{"The less you have the freer you are": Learning freeganism from the master of "simple living"}

Although Hong Kong is a highly Westernized society, Hongkongers' version of freeganism has followed a somewhat different trajectory. Unlike freegans in the West, who use the freegan lifestyle as "political theater" to protest against global capitalism and its excessive 
waste (Barnard 2011, 423), freegans in Hong Kong rarely emphasize the revolutionary potential of freeganism. Instead, they regard freeganism-which they call "simple living" (簡樸生活 gaanpok sangwut)—as a form of self-cultivation that will eventually lead them to greater personal freedom. This is not because they don't know that "the problem isn't just a few bad corporations but the entire system itself" (Freegan.info 2018). They are fully aware of it. But it is deeply ingrained in many Hong Kong people's minds that the laissezfaire economy is not only a key feature of a free society, but also what distinguishes Hong Kong from China's centralized economy, which they blame for the years of social and economic stagnation in mainland China. Thus, by extension, any outcry against capitalism risks being misunderstood as a stance in favor of Chinese-style socialism. For this reason, freegans in Hong Kong are wary of any claim that an overthrow of capitalism will bring about liberation. Rather, they opt for a softer approach that draws inspiration from Brother $\mathrm{Au}^{10}$ a highly respected figure who is regarded as an exemplar of "simple living" in the sinophone world.

Born in Macau in 1941, Brother Au moved to Taiwan to pursue a bachelor's degree in chemical engineering in the 1960s, hoping that a degree in chemistry would prepare him for the manufacturing boom at that time. After he graduated from National Taiwan University, he received a full scholarship to study polymer chemistry in Switzerland. Eight years later, Brother Au was headhunted by Taiwanese billionaire Wang Yung-ching to work for his Formosa Plastic Group, one of the largest plastic manufacturers in the world. Yet at the age of forty-two, he decided to leave this secure and well-paying job behind because, he said, he did not want to be "complicit" in a polluting industry. In a public talk in Hong Kong, he explained what brought him to this life-changing decision:

After working in the plastic plant for ten years, I started to ask myself if what I was doing was right, if the money I earned was moral, and what kind of person I wanted to become. The answer couldn't be clearer. As soon as I walked out of the plastic plant, I knew something was wrong. The air emitted from the plant smelled horrible and the water was black; needless to say, all the disposals from the plant were toxic; and it's still the case today. I didn't want to live against my conscience, so I quit my job. I think everyone should reflect on what they are doing and be mindful of the consequences of their actions (Au 2009).

After Brother Au quit his job at Formosa Plastic, he spent five years visiting different landfills, garbage dumps, recycling plants, and environmental organizations around the world to search for solutions to some of the most pressing environmental problems of our age. He then concluded that, since social change has to come from "a change of heart", the solution lies not in regulations and punishment but in the cultivation of an ethical self and the power of teaching by example-an approach that I call "chushi (出 世) asceticism". Through continual adherence to ethical self-cultivation, Brother Au set himself on a mission to show that it is possible to live a minimalist lifestyle without exploiting the environment. Notably, although Brother Au has done everything that a Western freegan would do, he has never attributed his "simple living" to the freegan movement in the West, nor has he ever claimed to have invented all of it himself, even though the freegans in Hong Kong all look up to him as an inspiration.

Eventually in 1988, Brother Au set up the Pure Land of Yanliao ${ }^{11}$ (鹽寮淨土 Yanliao Jingtu) on the coast of Hualien, Taiwan, as a base where he could show people what simple living means in everyday practice. The house is located in a tranquil fishing 
village that sits in the middle of two mountain ranges with a panoramic view of the Pacific Ocean. In Chinese, yan is the word for salt and liao the word for "simple houses". Because salt (yan) can preserve foods from putrefaction, the word yan carries Brother Au's wish that his simple living can preserve society from corruption and uphold certain virtues. Joined with the words jingtu, a Mahayana Buddhist term meaning "pure land", the Pure Land of Yanliao epitomizes Brother Au's ideal of a good society.

Brother Au's simple living has been guided by three broad principles: first, do no harm to humans, animals, and the environment; secondly, minimize your wants and desires in everyday life; and thirdly, learn to solve problems without money. Following the last principle, the Pure Land of Yanliao is free of charge and open to the public. Anyone is welcome to stay there as long as they respect the house rules and the ethics of simple living. This means visitors should bring their own bowls, chopsticks, cutlery, and handkerchiefs to the site, as single-use disposable products are banned. Moreover, there must be no consumption of meat, junk food, or alcohol at the time of their stay.

To "lead by virtue", Brother Au has led an ascetic but relatively self-sufficient life for the past 30 years in Taiwan and Hong Kong. He grows his own food, forages wild vegetables near his house, and scavenges discarded food and vegetables from nearby farmers' markets. Without fuel or tap water, Brother Au fetches water from a stream and cooks over an open fire. To prove to people that it is possible to live without much money or most modern amenities, Brother Au lives without a television, washing machine, computer, air conditioning, and toilet paper, ${ }^{12}$ all of which he says he has not used for over 20 years. ${ }^{13}$ The only modern amenities that Brother Au keeps are a refrigerator, a radio, and an old Nokia phone for him to stay in touch with the "outside world".

As a freegan, Brother $\mathrm{Au}$ is committed to not buying anything. Almost all of his material possessions were given to him by others. Even under difficult circumstances, he refuses to compromise his principle of "solving problems without money". For example, when he was looking for a permanent site in rural Hong Kong to build a second Pure Land of Yanliao, he insisted on finding a "landlord" who would let him use the land for free. Considering how expensive the rental market is in Hong Kong, it was an insurmountable challenge, yet he stood his ground. Eventually Brother Au's determination convinced the villagers of Yim Tin Tsai 鹽田梓 (Yim is the Cantonese for salt) to let him repurpose their abandoned village into a "Simple Living Camp" (簡樸 生活營地 gaanpok sangwut jingdei).

Frugality is another indispensable element of Brother Au's simple living. Take saving water as an example. While it is not uncommon that people save water by taking shorter showers or reusing grey water, Brother Au goes a step further to ensure that every drop matters. To demonstrate to people how little water they actually need every time they turn on the tap, he invented "water meditation" (水修行 seoi sauhang), a technique that uses an old water bottle to save water. Without tap water installed in his Simple Living Camp, Brother Au set up his own "running water" device with plastic water bottles collected from garbage bins. After filling the bottle with water, he carefully pierces two small holes at the bottom of the bottles so that water can flow through. The fine streams that come out from the holes not only serve as a sharp contrast to the running water in modern bathrooms but also force people to reflect on their wasteful behaviors in everyday life. 
Besides "water meditation", another self-cultivation practice that Brother Au introduced in his Simple Living Camp is "dining table meditation" (餐桌修行 caan coek sauhang). In essence, this is a technique to keep the dining table spotlessly clean so that it does not require cleaning after every use. For example, when people pour condiments like soy sauce on their food, the sauce may drip alongside the bottle, leaving a cup mark on the table surface. Although this mark can be easily removed with water or a cleaning product if the stain is stubborn, Brother Au suggests people take "preventive measures" to avoid making the table dirty in the first place: "We should pour the sauce as carefully as we pour dangerous chemicals in the laboratory. To avoid spilling and dripping when we pour, we can use a chopstick to 'lead' the liquid toward the direction we want", the former chemist explained. In Brother Au's view, "doing environmental protection" (做環保 zou waanbou) at the dinner table is a "more advanced form of environmentalism", because "dining table meditation" is not just about keeping the table clean but also a way of enhancing awareness about everyday waste. In simple living, even a few drops of soy sauce should be cherished.

These techniques of frugality have allowed Brother Au to live with relatively few resources and without worrying too much about money. When he was asked how much money he needed to survive on in an expensive city like Hong Kong, Brother Au said he had lived on \$200 Hong Kong dollars a month (approximately \$25 USD). By being frugal with his resources (e.g. using only a few drops of oil every time he cooks), a bottle of cooking oil lasts him for a year. As he scavenges most of his food, the only groceries that he needs to buy regularly are staple foods like rice and noodles.

As I mentioned earlier, both Foucault and Laidlaw argue that it is possible to exercise freedom by actively reflecting on the ethical question of how one ought to live (Foucault 1997, 284; Laidlaw 2002, 324). This line of thought coincides with that of Brother $\mathrm{Au}$, since the self-cultivation practices that he invented are not only intended to reduce pollution and waste but also to "set people free". He made this point clear in his autobiography, The Less You Have The Freer You Are: Twenty Years of Joyful SelfCultivation in Yanliao 《愈少愈自由: 覧寮樂修二十年》(Au 2008), in which he rejects the idea that freedom is the ability to do whatever one wants. Instead, he contends that real freedom can only be achieved when people liberate themselves from certain wants and desires. As a firm upholder of the principle that "happiness is not how much you have but how little you need", Brother Au believes that people's avarice for material goods not only leads to serious destruction of the environment, but that it is also the root of their sufferings, since they are being trapped in their own material possessions. "I never lock my door because I never need to worry about thieves", Brother Au laughed as he explained his rationale to his followers. "There's nothing to steal in my house. If someone takes something away from Yanliao, it must mean that he needs it. I'm happy to let him take what he needs!"

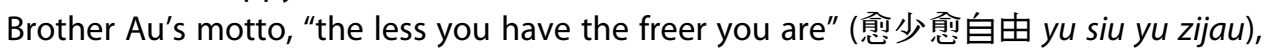
has been an inspiration for people who feel that they are trapped by money and material possessions. As a practitioner of simple living told me in an interview, "People today have become too dependent on money. We don't know how to live a life without money anymore. We are so used to solving problems with consumption that every time 
a problem arises, we go to the shop to buy a solution". Another interviewee concurred: "Hong Kong people only know the price but not the value of things. Whenever Hongkongers see a beautiful craft when they travel, the first thing they ask the local people is not how to make it, but how much it costs. I think it's pathetic".

Besides criticizing the "money trap", many of my informants think that the cost of convenience (方便的代價 fongbin dik doi gaa) is simply too high, as it is now costing them their environment and their freedom. As an audience member lamented during a public forum on environmental protection, "Convenience also has its downsides. If we had to walk two miles to dispose of our garbage, I bet we wouldn't produce so much waste!" In a similar vein, many people I interviewed concluded that convenience is depriving them of their "freedom of choice" because it has become more and more difficult to find nonchain stores and unbranded items in Hong Kong. Increasingly, 24/7 supermarket chains and convenience shops are putting family stores out of business. As one person said, "While the grocery shops in Thailand sell eight to ten "kinds" of sugar, the supermarket in Hong Kong sells eight to ten "brands" of the same sugar! People think Hongkongers are rich, but I think we're actually poor because our choices are so limited!"

After weighing the sacrifices that come with "having" and the kind of freedom that comes with "being without", people who do not want to trade their freedom for convenience find solace in Brother Au's "simple living". ${ }^{14}$ Hence for these people, the freedom that they pursue is not the freedom to do whatever they want without constraints, but the freedom that liberates them from certain wants and desires through abstinence and self-cultivation. Dr. Cheng, a Hong Kong physician who is greatly influenced by environmentalism and the philosophy of simple living, used this view of freedom to persuade his patients to give up smoking and become vegetarians. "Some patients will say to me, 'If I can't eat meat or smoke, what else can I enjoy in life?' And this is my answer to them: 'If you can't live without something, you're being controlled by it (界佢縛住 bei keoi bok zyu). You are not free! You are only free when you can live without something!'" I asked my informants, "I certainly see the appeal of this version of freedom. But are people willing to give up pleasure for it?" Zing, a follower of Brother Au, answered as follows: "If you truly want to set yourself free, you'll have the willpower to live the kind of life that Brother Au lives".

\section{Freecycling: a worldly and collective approach to freedom}

In spite of this, a complete freegan lifestyle is a rarity in Hong Kong. For one thing, most people cannot move to the country or live without some form of employment. Thus to a certain extent, freecycling is a compromise form of freeganism in Hong Kong. For example, twenty-two-year-old Gok is only able to lead a half-freegan life by eclectically incorporating Brother Au's teachings into his everyday practice. He gave up shopping entirely and scavenged most of his food from bakeries, supermarkets, and rubbish bins, but he hesitated to give up his tutoring job and become a hermit at such a young age. "It's true that most jobs are oppressive and enslaving, but I don't think I can survive without a job in Hong Kong. Hong Kong is an expensive city. Besides, I'd like to do something with my education and skills". 
Gok's concern is a common one among people who want to become freegan in Hong Kong. As I have demonstrated, while freegans seek liberation through "chushi (出世) asceticism", for freecyclers who seek to achieve freedom through "rushi (入世) asceticism", the attainment of freedom is no longer just an individual, other-worldly pursuit but a collective endeavor with a much stronger communitarian spirt. In the West, freegans are usually more radical and politically active than freecyclers (Aptekar 2016; Vinegar, Parker, and McCourt 2016), but the opposite is true in Hong Kong.

Although Freecycle.org in Hong Kong serves mainly English-speaking expatriates, there is no shortage of freecycling groups for Chinese-speaking communities. By 2015, there were about 50 Chinese-oriented freecycling groups in Hong Kong, most of which used Facebook as their online platform. "Oh Yes It's Free" (OYIF) ${ }^{15}$ was the most popular and influential freecycling group during the time of my fieldwork. Founded by a woman called Qing in July 2012, OYIF has developed its own distinctive objectives, jargon, and local meanings. Since almost everyone uses Facebook in Hong Kong, Qing decided to start a Facebook group to help these "unwanted items" find a new home. There is no additional sign-up procedure for Facebook users as there is with Freecycle.org. If you want to give away something that you no longer need, you will post a picture of the item on the OYIF group to "free" it to other members. You and the receiver will then arrange a time and a place to hand over the item. In Hong Kong, freecyclers use the English word "free" as a verb to mean "offer", one of the slang terms that arose organically in the OYIF Facebook group. Other slang terms include guk 谷 (group), guk jau 谷友 (freecyclers active in the freecycling group), paai 排 (queuing), jiu 要 (want), geoi 舉 (raise hand)-all of them being Cantonese shorthand for "I want this item".

Unlike most freecycling sites where ads are classified into different categories, OYIF purposely keeps its ads unclassified. The founder gave three reasons for this. First, she thinks there should be no restriction on what can and cannot be shared in the freecycling network. Known for her anti-authority and anti-establishment stance, Qing has refused to set up undemocratic rules or be the "boss" of the group. For her, everyone in the group can contribute to setting up rules. "I hope people would understand that self-discipline and responsibility are the foundations of a civilized society. If they follow the rules just to avoid punishment, their compliance will not be sustainable because those are actions without deliberation". This view clearly echoes with Honneth's point that belonging to an ethical community does not mean that the participants have given up their individual freedom, because there is always room for members of a democratic community to "renegotiate among themselves how they would like to apportion the responsibilities" in their collective pursuit of social freedom (Honneth 2017, 183).

Indeed, Qing and her comrades strongly believe that the concept of "waste" should be openly debated. For them, there is no such thing as "waste". "Waste is just misplaced resources" and "one person's trash could be another person's treasure" are two common refrains among the "green" people in Hong Kong. Thus OYIF does not restrict what can be "freed" or how an item should be reused or repurposed (as some freecycling groups do). Instead, it encourages people to be creative and open-minded about the process of reusing, recycling, and upcycling. For example, some women have offered their breast milk to new mothers with low milk supply-a practice not without 
controversy. ${ }^{16}$ There have also been specialized groups for giving away leftover dinners, expired food, water kefir grains, and eco-enzymes (a multipurpose cleaning solution fermented from fresh kitchen waste). Another unusual item that can be found on OYIF is soft-drink pull tabs. In 2012, a freecycler launched an initiative on OYIF to collect soft-drink pull tabs for the Prostheses Foundation in Thailand, which uses recycled materials from plastic yogurt bottles and aluminum-can tabs to build prosthetic legs for amputees. Once enough pull tabs are collected, they are then transported to Thailand by a volunteer vacationer from Hong Kong. In this case, freecycling has been turned into a grassroots philanthropy initiative.

In addition to "freeing" things, some freecyclers in Hong Kong have volunteered to "free" their skills to their communities. "Oh Yes It Can Be Fixed", an affiliate group derived from "Oh Yes It's Free", matches amateur repairers with owners of broken appliances. Other skills and services that have been offered for free include proofreading, English tutoring, hairdressing, and changing batteries in watches and smartphones.

At one point, OYIF attracted over 70,000 members. As the freecycling movement gained momentum, OYIF wanted to do more than just provide people with an online platform to give and receive things for free. It soon became a vocal critic of Hong Kong's consumerist culture and an ardent advocate of mutual aid, grassroots activism, and sustainable living. In 2012, OYIF collaborated with Nobanker Youth Commune Freespace (無莊青年公社), a community project that emerged in the aftermath of the Occupy Central protest, ${ }^{17}$ to experiment with "offline" freecycling and the idea of communal living in Hong Kong. The Freespace collaborative project was self-funded by the founder of OYIF and a group of young people who wanted to reduce not just waste but also poverty and inequality in Hong Kong. In a radio interview, Qing recalled how the collaboration came into being: "Before I knew my friends at Freespace, I and OYIF were only focusing on the environmental impact of waste. On the contrary, the environment wasn't the key focus of people at Freespace. They were more interested in social justice and alleviating poverty. Even though we started off with different interests, we're complementary to each other and we soon found our common ground". ${ }^{18}$

Against all odds, the activists and volunteers managed to raise enough funds to rent a three-thousand-square-feet industrial warehouse for items that would have otherwise ended up in landfill. ${ }^{19}$ Like OYIF, Freespace not only saved items that were in good condition but also those that were apparently damaged and beat up. For example, although handbags made with polyurethane cannot be mended once they are worn out, the freecyclers would disassemble the zippers and buckles and save them for other uses. In doing so, Freespace had rescued tens of thousands of discarded items and repaired hundreds of them within four months. Walking through the warehouse, one finds shelves made of used cardboard boxes holding rags, rope, hangers, cutlery, plates, bowls, ripped T-shirts, juice cartons, glass bottles, expired cooking oil, tea, spices, flour, residual paint, screws, door hinges, pieces of wood, and so on. As people came to Freespace regularly, the warehouse soon became a gathering place for like-minded individuals to explore freecycling and the possibility of communal freeganism in Hong Kong. People came together to share food, knowledge, skills, and ideas, cooked meals for each other using food discarded by supermarkets, transformed broken umbrellas into hooks and raincoats, upcycled wooden panels into bookcases, 
and even created a small library with donated books. As this new dynamic evolved into a prefigurative form of communal freeganism, the freecyclers realized that they did not need to be hermits living in remote mountains in order to be free. They saw that the pathway to freedom - that is, taking responsibility through ethical practicesdid not have to be a solo effort. By means of sharing, recycling, and bartering, these freecyclers challenged the deep-seated idea that a laissez-faire economy is a defining feature of freedom in Hong Kong. They argued for a different kind of "free market", one that they called the "Really, Really Free Market (RRFM)", ${ }^{20}$ in which freedom is achieved collectively by taking responsibility and by engaging with society in an "ethical" manner. I call such an approach to freedom rushi asceticism.

Although the Freespace experiment fell through in March 2014 due to a lack of funds, freecyclers in Hong Kong have continued to find ways to exercise their social freedom by engaging with their own communities. ${ }^{21}$ "Flash-mob" freecycling, or faai sim 快閃, is one such example. Oxford Dictionaries define a "flash mob" as a large public gathering, typically organized by means of the Internet or social media, at which people "perform an unusual or seemingly random act and then disperse". In a flash-mob freecycling event, people from the same neighborhood, mostly women and their children, congregate in a park and lay out on the ground all the goods they want to give away. They disperse as soon as authorities (e.g. police or security guards) intervene. Since it is illegal to be a hawker without a license in Hong Kong, freecyclers have to carry placards that read "Just giving, no selling" (只送不賣 zhi sung bat maai) or "it's better to give it away than to let it collect dust" (與其封塵，不如送人 jyu kei fungcan, bat jyu sungjan) wherever they go. As one organizer told me, "We want to be absolutely clear that there is no money involved". While the women were busy laying items out on the ground, children had fun patrolling with the placards and telling participants and onlookers about the rules of flash-mob freecycling. In a certain way, this activity resembles what used to be a relatively self-sufficient way of life in Hong Kong. Until the 1970s, hawkers were allowed to earn a modest living by selling a variety of food and goods on the street. But as Hong Kong transformed itself into "Asia's World City", street hawkers were deemed too unsightly to remain (Smart 1989). The guerrilla tactics of such flash mobs empower these freecyclers to exercise their "right to the city" (Harvey 2008) by reclaiming public places that have been increasingly bureaucratized and sanitized to eliminate all ungoverned activities. Flash-mob freecycling liberates people from such control and gives them a sense of positive freedom, however transient it may be.

\section{Conclusion}

The idea that freedom is the natural faculty to do whatever one wants so long as it does not break the law is often taken for granted in the modern world. One needs look no further than the Universal Declaration of Human Rights (UDHR). First proclaimed by the United Nations in 1948, the UDHR was the first document to declare that "all human beings are born free" and that freedom is the "highest aspiration" for all people and all nations (United Nations 1998). ${ }^{22}$ However, if we probe into the genealogy of "freedom", which has its origin in Roman law, it becomes clear that its meaning changed dramatically over the centuries (Graeber 2013). As Graeber elaborates: 
As everywhere in the ancient world, to be "free" meant, first and foremost, not to be a slave. Since slavery means above all the annihilation of social ties and the ability to form them, freedom meant the capacity to make and maintain moral commitments to others [my emphasis]. The English word "free," for example, is derived from a German root meaning "friend," since to be free meant to be able to make friends, to keep promises, to live within a community of equals. This is why freed slaves in Rome became citizens: to be free, by definition, meant to be anchored in a civic community, with all the rights and responsibilities that this entailed. (Graeber 2011, 203)

However, by the second century $C E$, the meaning of freedom had evolved from "making friends" to mean a natural right to do "whatever one wishes that is not prevented by force or law" (Graeber 2011, 204). With the early definition of freedom, to be free was "to be anchored in a civic community" because only free men and women would have social responsibilities and moral commitments $(2011,203)$. However, when freedom is conceived of as a natural right without such obligations, "it leaves it very hard to imagine what meaningful human freedom would even be like" $(2011,385)$, since rights and obligations are two sides of the same coin. One person's right is another person's obligation.

In this light, Graeber calls for a resurrection of the older notion of freedom as the ability to act together for a common good (2013). As my article has shown, this view of freedom not only coincides with what Laidlaw argues about ethics and freedom, it is also reflected in the practices and philosophy of the freegans and freecyclers in Hong Kong. While freecyclers achieve freedom by actively engaging with the world to foster social changes (入世 rushi asceticism), freegans seek liberation by withdrawing from the world to cultivate the ethical self (出世 chushi asceticism). In both cases, the freedom to which they aspire is not a freedom without constraints (i.e. negative freedom) but a freedom that encourages self-denial and self-realization for a common good (i.e. positive freedom and social freedom). By reimagining freedom as the ability to be an ethical being rather than a right that comes naturally with birth and without obligations, freegans and freecyclers in Hong Kong demonstrate that the attainment of freedom, however paradoxical it sounds, can be achieved through an exercise of self-discipline rather than self-indulgence.

\section{Notes}

1. All Chinese words in this article are Cantonese romanizations except the words freedom (ziyou), rushi, and chushi as they are likely to be the search terms for scholars researching freedom and/or ethical practices in China. For ease of access, the romanization of these three terms are in standard Mandarin Pinyin. Cantonese romanizations follow the Jyutping system.

2. "Freedom" was listed as the number one core value in a press declaration signed by over 300 professionals and academics in 2004. More recently, a telephone survey conducted by the Chinese University of Hong Kong in 2015 found that $88 \%$ of respondents agreed that "freedom" was one of the core values of Hong Kong society. See Communication and Public Relations Office (2015).

3. See Reporters Without Borders (2017).

4. In September 2017, a widely publicized workshop entitled "Hong Kong and Liberty" was held at the Chinese University of Hong Kong.

5. See Chow (2015). 
6. Berlin's "Two Concepts of Liberty" was originally delivered as a lecture in Oxford in 1958. It was subsequently published in Four Essays on Liberty (Berlin 1969).

7. Political philosophers have debated the difference between liberty and freedom at both the conceptual and semantic levels. While some philosophers, such as Berlin (1969) and Cranston (1954), maintain that the terms can be used interchangeably, others, such as Arendt (1990) and Pitkin (1988), insist that they are not the same. In this paper, I follow Isaiah Berlin and use freedom and liberty interchangeably.

8. Berlin $(1969,131)$ wrote: "I wish my life and decisions to depend on myself, not on external forces of whatever kind. I wish to be the instrument of my own, not of other men's acts of will. I wish to be a subject, not an object... a doer-deciding, not being decided for; self-directed and not acted upon by external nature.... I wish, above all, to be conscious of myself as a thinking, willing, active being, bearing responsibility for my choices and able to explain them by references to my own ideas and purposes".

9. Although Foucault's earlier work on biopower and governmentality have given the impression that he denied the possibility of freedom, he rejected "the idea that power is a system of domination that controls everything and leaves no room for freedom" (Foucault 1997, 293). In his later years, he shifted his attention to the idea of ethical self-cultivation by analyzing the Late Antiquity practices of epimelesthai sautou ("to be concerned, to take care of oneself") as "technologies of the self" (Foucault 1988).

10. With the exception of public figures like Brother Au and Qing, all individual names are pseudonyms.

11. The place name Pure Land of Yanliao is in Mandarin Pinyin because the base was set up in Taiwan.

12. When Brother Au goes to the toilet, he brings a small cup of water to clean himself afterwards. This practice has allegedly put some Hong Kong people off from visiting the Pure Land of Yanliao, as toilet paper is not allowed there.

13. It is important to understand that Brother $\mathrm{Au}$ is not advocating a return to a premodern way of living. As he said himself, his way of life should not be treated as a universal truth and he does not expect anyone to live like him in the twenty-first century. He said that all he wants to do is to send a message to the society that "happiness is not how much you have but how little you need" by setting a good example.

14. Most aspiring freegans whom I interviewed took their inspirations from Brother Au's "simple living," except for one informant (twenty-two-year-old Gok), who said he learned about freeganism through an American anarchist. More recently, the Taiwanese freegan Yang Zhonghan and his book Notes in Ruin: The Freedom of Freeganism 《空屋筆記：免費 的自由》(2017) has gained attention in Hong Kong. However, during my fieldwork in 2012-2013, no one mentioned Yang to me.

15. The group uses the name "Oh Yes It's Free" in English and has no Chinese name.

16. Most "green" mothers in Hong Kong perceive infant formula as an unhealthy manufactured food sold by unscrupulous businesses and recommend complete avoidance of infant formula. However, the exchange of breastmilk has also provoked controversy about safety and hygiene.

17. Occupy Central was part of the international occupation protest movement against social and economic inequality. It took place in Central Hong Kong between 2011 and 2012. Occupy Central should not be confused with the Occupy Central with Love and Peace (later known as the Umbrella Movement) in Hong Kong in 2014.

18. The quote was excerpted from a radio interview originally uploaded to Youtube, but it was later taken down due to copyright infringement. I am unable to provide the original source/URL here but I recalled that Qing has reiterated the collaboration story in her other media interviews as well, so it was a widely known fact.

19. Most of the items are large furniture, as wood recycling is currently unavailable in Hong Kong.

20. See Really Really Free Market: https://reallyreallyfreemarket.weebly.com/oh-yes-its-free.html [accessed 28 June 2018]. 
21. One of the major debates in the study of freecycling is whether the initiative can bring the community together and engender new forms of civic life. In their study of Freecycle.org users in the United States, Nelson, Rademacher, and Paek $(2007,152)$ found that freecycling does play a part in both offline and online civic participation. Likewise, Sari's thesis shows that Freecycle.org "redefines the way citizenship is practiced" and pushes forward "individual interests into community participation" in daily life (Sari 2010, 2). In contrast, Aptekar is more doubtful of the promise of freecycling. Her research found that members of Freecycle.org are motivated to give so that they could declutter their homes in an environmentally friendly fashion and in a way that can "expiate guilt from overconsumption." Altruism and solidarity only come second among the Freecycle.org members she studied (Aptekar 2016, 266).

22. The milestone document, first promulgated in 1948, declares that all human beings "are born free and equal in dignity and rights" (Article 1). They "shall enjoy freedom of speech and belief and freedom from fear and want" (Preamble). See United Nations (1998).

\section{Acknowledgements}

I would like to thank the editors and the two anonymous reviewers for their helpful comments and suggestions.

\section{Disclosure statement}

No potential conflict of interest was reported by the author.

\section{Funding}

No external sources of funding were used for this research.

\section{Notes on contributor}

Loretta leng Tak Lou is a Lecturer and Macao Fellow in Social Sciences at the University of Macau. Her research interests lie in the areas of environment, well-being, social movements, morality and ethics in Greater China. She is currently on research leave in the Department of Anthropology at the London School of Economics and Political Science (LSE).

\section{ORCID}

Loretta leng Tak Lou (D) http://orcid.org/0000-0002-5944-1447

\section{References}

Ankeny, Rachel A. 2012. "Food and Ethical Consumption." In The Oxford Handbook of Food History, edited by Jeffrey M. Pilcher, 461-480. Oxford: Oxford University Press.

Aptekar, Sofya. 2016. "Gifts Among Strangers: The Social Organization of Freecycle Giving." Social Problems 63 (2): 266-283. doi:10.1093/socpro/spw005.

Arendt, Hannah. 1990. On Revolution. London: Penguin Books.

$\mathrm{Au}$, Brother. 2008. 《㸝少愈自由: 鹽寮樂修二十年》(The Less You Have the Freer You Are:

Twenty Years of Joyful Self-Cultivation in Yanliao.). 台灣 [Taiwan]: 心靈工坊 [Psygarden]. 
Au, Brother. 2009. “區紀復講座摘要：愈少愈自由” [Summary of Au's Talk: The Less You Have the Freer You Are]. Talk presented at Club O on 26 December. Hong Kong S.A.R. Transcribed by Kwuntung Tse. Accessed May 6 2017. http://www.inmediahk.net/node/1005503

Barnard, Alex V. 2011. "Waving the Banana at Capitalism: Political Theater and Social Movement Strategy among New York's 'Freegan' Dumpster Divers." Ethnography 12 (4): 419-444. doi:10. $1177 / 1466138110392453$.

Berlin, Isaiah. 1969. "Two Concepts of Liberty." In Four Essays on Liberty, 118-172. Oxford: Oxford University Press.

Brook, Timothy. 1994. Praying for Power: Buddhism and the Formation of Gentry Society in Late Ming China. Cambridge, MA: Harvard University Press.

Carrier, James G., and Peter Luetchford, eds. 2012. Ethical Consumption: Social Value and Economic Practice. Oxford: Berghahn.

Carter, lan. 2016. "Positive and Negative Liberty." In Stanford Encyclopedia of Philosophy, edited by Edward N. Zalta. Stanford, CA: Stanford Center for the Study of Language and Information. Accessed May 5 2017. https://plato.stanford.edu/entries/liberty-positive-negative/

Chow, Po Chung. 2015. 《政治的道德: 從自由主義的觀點看》 [Political Morality: From a Liberal Point of View]. Hong Kong: Chinese University Press.

Connolly, John, and Andrea Prothero. 2008. "Green Consumption: Life-Politics, Risk and Contradictions." Journal of Consumer Culture 8 (1): 117-145. doi:10.1177/1469540507086422.

Communication and Public Relations Office. 2015. "CUHK Releases Survey Findings on Views on Hong Kong's Core Values." Hong Kong: Chinese University of Hong Kong. Accessed April 2 2019. https://www.cpr.cuhk.edu.hk/en/press_detail.php?id=2113\&t=cuhk-releases-survey-findings-on-views-on-hong-kong-s-core-values\&s=core\%20values

Cranston, Maurice. 1954. Freedom: A New Analysis. London: Longmans.

De Neve, Geert, Peter Luetchford, Jeffery Pratt, and Donald C. Wood, eds. 2012. Hidden Hands in the Market: Ethnographies of Fair Trade, Ethical Consumption and Corporate Social Responsibility. Bingley: Emerald Group.

Dyring, Rasmus. 2018. "From Moral Facts to Human Finitude: On the Problem of Freedom in the Anthropology of Ethics." HAU: Journal of Ethnographic Theory 8 (1-2): 223-235. doi:10.1086/ 698433.

Eden, Sally. 2017. "Blurring the Boundaries: Prosumption, Circularity, and Online Sustainable Consumption through Freecycle." Journal of Consumer Culture 17 (2): 265-285. doi:10.1177/ 1469540515586871.

Edwards, Ferne, and Dave Mercer. 2012. "Food Waste in Australia: The Freegan Response." Sociological Review 60 (2_suppl): 174-191. doi:10.1111/1467-954X.12044.

Ernst, Kelly. 2010. "'A Revolution We Create Daily': Freegan Alternatives to Capitalist Consumption in New York City." PhD diss., American University.

Fassin, Didier. 2014. "The Ethical Turn in Anthropology: Promises and Uncertainties." HAU: Journal of Ethnographic Theory 4 (1): 429-435. doi:10.14318/hau4.1.025.

Foucault, Michel. 1988. Technologies of the Self: A Seminar with Michel Foucault, edited by Luther H. Martin, Huck Gutman, and Patrick H. Hutton. Amherst: University of Massachusetts Press.

Foucault, Michel. 1997. Essential Works of Foucault 1954-1984, Vol. 1: Ethics: Subjectivity and Truth, edited by Paul Rabinow, translated by Robert Hurley and others. New York: Penguin Books.

Freecycle.org. 2019. "History \& Background Information." Accessed March 2019. https://www. freecycle.org/about/background

Freegan.info. 2018. "Strategies for Sustainable Living Beyond Capitalism." Accessed July 122018. https://freegan.info/

Goodman, David, E. Melanie DuPuis, and Michael K. Goodman. 2013. Alternative Food Networks: Knowledge, Practice, and Politics. London: Routledge.

Graeber, David. 2011. Debt: The First 5,000 Years. New York: Melville House.

Graeber, David. 2013. "Two Notions of Liberty Revisited-Or, How to Disentangle Liberty and Slavery." openEconomy (19 May). Accessed June 24 2018. https://www.opendemocracy.net/ 
openeconomy/david-graeber/two-notions-of-liberty-revisited-or-how-to-disentangle-libertyand-slavery.

Harvey, David. 2008. "The Right to the City." New Left Review 53: 23-40.

Heywood, Paolo. 2015. "Freedom in the Code: The Anthropology of (Double) Morality." Anthropological Theory 15 (2): 200-217. doi:10.1177/1463499614568498.

Honneth, Axel. 2017. "Three, Not Two, Concepts of Liberty: A Proposal to Enlarge Our Moral Self-Understanding." In Hegel on Philosophy in History, edited by Rachel Zuckert and James Kreines, 177-192. Cambridge: Cambridge University Press.

Keane, Webb. 2014. "Freedom, Reflexivity, and the Sheer Everydayness of Ethics." HAU: Journal of Ethnographic Theory 4 (1): 443-457. doi:10.14318/hau4.1.027.

Kelty, Christopher M. 2011a. "The Anthropology of Freedom, Part 1." Savage Minds (6 July). Accessed May 7 2017. https://savageminds.org/2011/07/06/the-anthropology-of-freedom-part-1/

Kelty, Christopher M. 2011b. "The Anthropology of Freedom, Part 2." Savage Minds (8 July). Accessed May 7 2017. https://savageminds.org/2011/07/08/the-anthropology-of-freedom-part-2/

Krøijer, Stine. 2015. "Revolution Is the Way You Eat: Exemplification among Left Radical Activists in Denmark and in Anthropology." Journal of the Royal Anthropological Institute 21 (S1): 78-95. doi:10.1111/1467-9655.12167.

Laidlaw, James. 2002. "For an Anthropology of Ethics and Freedom." Journal of the Royal Anthropological Institute 8 (2): 311-332. doi:10.1111/1467-9655.00110.

Laidlaw, James. 2014. The Subject of Virtue: An Anthropology of Ethics and Freedom. Cambridge: Cambridge University Press.

Laidlaw, James. 2017. "Ethics/morality." In The Cambridge Encyclopedia of Anthropology, edited by F. Stein, S. Lazar, M. Candea, H. Diemberger, J. Robbins, A. Sanchez, and R. Stasch. Accessed June 24 2019. doi:10.29164/17ethics

Lewis, Tania, and Emily Potter, eds. 2011. Ethical Consumption: A Critical Introduction. London: Routledge.

Lou, Loretta leng Tak. 2016. "Healing Nature: Green Living and the Politics of Hope in Hong Kong." PhD thes., University of Oxford.

Lyon, Sarah M., and Mark Moberg, eds. 2010. Fair Trade and Social Justice: Global Ethnographies. New York: New York University Press.

Moré, Victoria. 2011. "Dumpster Dinner: An Ethnographic Study of Freegangism." Journal of Undergraduate Ethnography 1: 43-55.

Nicholls, Alex, and Charlotte Opal. 2005. Fair Trade: Market-Driven Ethical Consumption. London: Sage.

Nelson, Michelle R, Mark A. Rademacher, and Paek Hye-Jin. 2007. "Downshifting Consumer $=$ Upshifting Citizen? An Examination of a Local Freecycle Community." Annals of the American Academy of Political and Social Science 611 (1): 141-156. doi:10.1177/ 0002716206298727.

Pang, Laikwan. 2018. "Between Liberty and Equality: Lessons from Hong Kong." Global-e 11 (3): 1-6. Accessed April 2 2019. https://www.21 global.ucsb.edu/global-e/january-2018/betweenliberty-and-equality-lessons-hong-kong

Pitkin, Hanna Fenichel. 1988. "Are Freedom and Liberty Twins?" Political Theory 16 (4): 523-552. doi:10.1177/0090591788016004001.

Reporters Without Borders. 2017. "Media Freedom in Free Fall 20 Years after Hong Kong Returned to China." Accessed April 2 2019. https://rsf.org/en/news/media-freedom-free-fall-20years-after-hong-kong-returned-china

Robbins, Joel. 2007. "Between Reproduction and Freedom: Morality, Value, and Radical Cultural Change." Ethnos: Journal of Anthropology 72 (3): 293-314. doi:10.1080/00141840701576919.

Sari, Pamela. 2010. "Offer, Wanted, Taken: Laramie Freecycle and the Redefinition of Everyday Meanings of Citizenship." MA thes., University of Wyoming.

Schut, Thijs, and Erella Grassiani. 2017. "Introduction: Freedom." Etnofoor 29 (1): 7-10.

Smart, Josephine. 1989. The Political Economy of Street Hawkers in Hong Kong. Hong Kong: Centre of Asian Studies. 
United Nations. 1998. The Universal Declaration of Human Rights, 1948-1998. New York: United Nations Department of Public Information. Accessed May 4 2017. http://www.un.org/en/universal-declaration-human-rights/

Vinegar, Russell, Pete Parker, and George McCourt. 2016. "More than a Response to Food Insecurity: Demographics and Social Networks of Urban Dumpster Divers." Local Environment 21 (2): 241-253. doi:10.1080/13549839.2014.943708.

Weber, Max. 1922. 1978. Economy and Society: A Outline of Interpretative Sociology. Berkeley: University of California Press. 